\title{
ANALISIS FAKTOR PENYEBAB DAN PENANGANAN PEMBIAYAAN MURABAHAH BERMASALAH: STUDI KASUS PADA BMT GUNUNGJATI, CIREBON
}

Rafi Farizki, Komarudin

Green Publisher

E-mail : rafifarizki90@gmail.com, jrxkomarudin21@gmail.com

\section{Abstrak}

Transaksi murabahah yang dilakukan di BMT, lebih sering digunakan untuk pembiayaan yang ditujukan kepada nasabah untuk tambahan modal kerja. Seperti pembiayaan untuk memperluas usaha. Di dalam akad pembiayaan murabahah di BMT berdasarkan pada asas jual-beli, BMT bertindak sebagai penjual dan mitra usaha sebagai pembeli atau nasabah. Harga jual ditentukan berdasarkan harga beli dasar ditambah mark-up sesuai dengan kesepakatan antara BMT dengan mitra usaha. Penelitian ini bertujuan menganalisis faktor penyebab dan penanganan pembiayaan murabahah bermasalah. Pelitian ini menerapkan metode kajian pustaka pada kualiatatif deskriptif. Dan menggunakan analisis isi pada data yang diambil dari dokumen atau catatan. Faktor yang menyebabkan pembiayaan murabahah bermasalah di BMT Gunungjati dikarenakan pihak BMT (faktor insternal) dan nasabah itu sendiri (faktor eksternal) seperti: Penurunan pendapatan usaha yang diperoleh nasabah, nasabah mengalami kepailitan dan nasabah kesulitan dalam melakukan pembayaran. Sehingga dilakukan penanganan dengan cara dilakukan penjadwalan kembali (rescheduling), penyusunan kembali (restructuring), offset pinjaman (penjualan jaminan) dan penghapusan pembiayaan.

Kata Kunci: Faktor Penyebab, Penanganan Pembiayaan, Murabahah Bermasalah

\section{Abstract}

Murabahah transactions carried out at BMT are more often used for financing aimed at customers for additional working capital. Such as financing to expand the business. In the murabahah financing contract at BMT based on the principle of buying and selling, the BMT acts as the seller and the business partner as the buyer or customer. The selling price is determined based on the basic purchase price plus a mark-up in accordance with the agreement between BMT and business partners. This study aims to analyze the causes and treatment of problematic murabahah financing. This research applies the literature review method in descriptive qualitative. And use content analysis on data extracted from documents or records. The factors that cause murabahah financing to be problematic at BMT Gunungjati are due to the BMT

\begin{tabular}{ll}
\hline & Rafi Farizki, Komarudin. (2020). Analisis Faktor Penyebab Dan Penanganan Pembiayaan \\
& Murabahah Bermasalah: Studi Kasus Pada Bmt Gunungjati, Cirebon. Co-Value: Jurnal \\
How to cite: & Ekonomi, Koperasi Kewirausahaan Vol 11(2):42-49 \\
E-ISSN: & https://greenpublisher.id/ \\
\hline Published by: &
\end{tabular}


(internal factors) and the customers themselves (external factors) such as: Decreased operating income obtained by customers, customers experiencing bankruptcy and customers having difficulty making payments. So that the handling is done by rescheduling, restructuring, loan offsets (sale of guarantees) and the elimination of financing.

Keywords: Causing Factors, Handling Financing, Troubled Murabaha

Diterima: 25-06-2020 Direvisi: 5-07-2020 Disetujui: 6-07-2020

\section{PENDAHULUAN}

Islam adalah agama yang maha sempurna, oleh karenanya tidak ada satu aspek pun dalam persoalan manusia yang luput dari kajian dan perhatian Islam (Purwanto, 2019). Allah swt telah merumuskan dan menyempurnakan segala bentuk aturannya untuk dijadikan sebagai panduan bagi segenap umat Islam (Al-Hasan, 2013). Begitupun dalam urusan muamalah, Islam mempunyai fondasi, aturan dasar atau pengarahan yang pokok dan beberapa cabang penting dalam Ekonomi Islam, yang segogyanya menjadi acuan dasar bagi umat islam dalam menjalankan kegiatan muamalahnya (Al-Hasan, 2013).

BMT sebagai lembaga keuangan yang ditumbuhkan dari peran masyarakat secara luas tidak ada batasan ekonomi, sosial, bahkan agama. Semua komponen masyarakat dapat berperan aktif dalam membangun sebuah sistem keuangan yang lebih adil dan mampu menjangkau lapisan pengusaha yang terkecil sekalipun (Mustofa, 2014). Keberadaan BMT di Indonesia telah menjadi alternatif penyedia jasa keuangan untuk pembiayaan mikro Islam. Dimana ada 3 hal yang mendasari pernyataannya tersebut. Pertama, BMT didirikan di sebuah komunitas kecil. Kedua, hal itu dibuktikan bahwa BMT telah memberantas praktek rentenir. Ketiga, BMT bisa bertahan ketika krisis keuangan global melanda stabilitas perekonomian Indonesia pada tahun 2008 (Wardiwiyono, 2012).

Berdasarkan keputusan Menteri Koperasi RI No.91/Kep/M.KUM/2004, BMT sekarang berbentuk Koperasi Jasa Keuangan Syari'ah (BMT). Pengelolaan BMT difokuskan kepada sektor keuangan berupa penghimpunan dana dan pendayagunaannya. Salah satu produk BMT adalah murabahah, Secara singkat, murabahah berarti suatu penjualan barang seharga barang tersebut ditambah keuntungan yang disepakati. Transaksi murabahah yang dilakukan di BMT, lebih sering digunakan untuk pembiayaan yang ditujukan kepada nasabah untuk tambahan modal kerja. Seperti pembiayaan untuk memperluas usaha. Di dalam akad pembiayaan murabahah di BMT berdasarkan pada asas jual-beli, BMT bertindak sebagai penjual dan mitra usaha sebagai pembeli atau nasabah. Harga jual ditentukan berdasarkan harga beli dasar ditambah mark-up sesuai dengan kesepakatan antara BMT dengan mitra usaha. (Laina, 2016).

\section{METODE PENELITIAN}

Pelitian ini menerapkan metode kajian pustaka pada kualiatatif deskriptif. Dan menggunakan analisis isi pada data yang diambil dari dokumen atau catatan.

\section{HASIL DAN PEMBAHASAN}

\section{A. Praktek Pembiayaan Murabahah dan Konsep Murabahah dalam islam}


Murabahah adalah salah satu akad jual beli (pembiayaan) dengan tambahan nilai yang diberikan oleh pembeli kepada penjual (LKS) sebagai laba untuk penjual sesuai dengan kesepakatan. Murabahan merupakan salah satu jual beli al Amanah, dikarenakan jual beli ini terjadi berdasarkan kepercayaan kepada penjual yang menjelaskan tentang harga beli terhadap barang tersebut. Jual beli lainnya yang termasuk pada kategori ini adalah jual beli Tawliyah (tanpa mengambil keuntungan) dan jual beli Muawwadah ( di bawah harga/diskon). Dikarenakan Murabahah merupakan salah satu jenis dari Jual beli, maka landasan hukum dan rukunnya sama dengan jual beli pada umumnya. Diantara dalil yang menjadi landasannya adalah, Q.S Al-Baqarah: 275 dan Q.S An-Nisa: 26

“... dan Allah telah menghalalkan jual beli dan mengharamkan riba.

....” (Q.S Al-Baqarah: 275)

“...janganlah kamu saling memakan harta sesamamu dengan jalan yang batil, kecuali dengan jalan perniagaan yang berlaku dengan suka sama-suka di antara kamu....."( Q.S An-Nisa: 26).

Akad atau transaksi murabahah seharusnya dilaksanakan dengan dua akad. Pertama akad dari suplayer kepada pihak BMT dan yang kedua adalah akad dari pihak BMT ke nasabah, sesuai dengan apa yang durumuskan oleh para ulama (Al-Hasan, 2013). Dalam transaksi murabahah tidak diperkenankan dijalankan berdasarkan ba'i alMurabahah bil wakalah atau melalui perwakilan kepada nasabah, karena ini lebih dekat dengan jual beli terhadap benda yang belum ada, dan itu tidak diperbolehkan dalam islam (Al-Hasan, 2013).

Dalam prakteknya BMT yang hanya memberikan uang kepada nasabah untuk dibelikan sendiri baranganya atau pihak BMT menunjuk nasabah sebagai agennya untuk membeli barang yang diperlukannya atas nama BMT yang bersangkutan dan menyelesaikan pembayaran harga barang dari biaya BMT tersebut (Yuliansyah, 2013). Mekanisme ini jelas menyalahi hakikat murabahah itu sendiri, yang pada hakikatnya murabahah adalah proses jual beli yang syarat dan rukun nya di tentukan oleh aturan syara". Apabila pola ini tetap dilakukan, maka kesan yang kita dapat dari proses ini penjual menjual barang yang belum ia miliki padahal ini jelas menyalahi aturan syarae Sebagaimana dalam hadits dikatakan, "Tidaklah sah jual beli, kecuali uyang dapat dimiliki."(HR. Abu Dawud 7083).

\section{B. Pedoman Standar Akuntansi Dan Keuangan (PSAK) No. 102}

Baitul Maal wa Tamwil (BMT) menyalurkan dana dalam bentuk jual beli dalam pembayaran ditangguhkan adalah penjualan barang dari BMT kepada nasabah, dengan harga ditetapkan sebesar biaya perolehan barang ditambah margin keuntungan yang disepakati untuk keuntungan BMT. (Febrian \& Mardian, 2017). Dalam murabahah BMT bertindak sebagai penjual dan juga pembeli, sebagai pembeli BMT membeli barang kepada pemasok untuk dijual kepada nasabah. Perlakuan akuntansi murabahah di BMT berdasarkan PSAK 102 yang berhubungan dengan pengakuan, pengukuran, penyajian, dan pengungkapkan murabahah (R. Ibrahim \& Handayani, 2009).

Berdasarkan PSAK 102 akuntansi murabahah pengakuan, pengukuran, penyajian, dan pengungkapan akuntansi untuk penjual adalah sebagai berikut:

1. Pada saat perolehan, aset murabahah diakui sebagai persediaan sebesar biaya perolehan.

2. Pengukuran aset murabahah setelah perolehan adalah sebagai berikut: 
a. Jika murabahah pesanan mengikat: dinilai sebesar biaya perolehan dan jika terjadi penurunan nilai aset karena usang, rusak, atau kondisi lainnya sebelum diserahkan kenasabah, penurunan nilai tersebut diakui sebagai beban dan mengurangi nilai aset (Febrian \& Mardian, 2017).

b. Jika murabahah tanpa pesanan atau murabahah pesanan tidak mengikat: dinilai berdasarkan biaya perolehan atau nilai bersih yang dapat direalisasi, mana yang lebih rendah dan jika nilai bersih yang dapat direalisasi lebih rendah dari biaya perolehan maka selisihnya diakui sebagai kerugian (Habibah \& Nikmah, 2016).

3. Diskon pembelian aset murabahah diakui sebagai berikut:

a. Jika terjadi sebelum akad murabahah maka sebagai pengurangan biaya perolehan aset murabahah.

b. Jika terjadi setelah akad murabahah dan sesuai akad yang disepakati maka bagian yang menjadi hak nasabah dikembalikan kepada nasabah jika nasabah masih berada dalam proses penyelesaian kewajiban atau kewajiban kepada nasabah jika nasabah telah menyelesaikan kewajiban (A. Ibrahim \& Rahmati, 2017).

c. Jika terjadi setelah akad murabahah dan sesuai akad yang menjadi bagian hak lembaga keuangan syariah diakui sebagai tambahan keuntungan murabahah.

d. Jika terjadi setelah akad murabahah dan tidak diperjanjikan dalam akad diakui sebagai pendapatan operasional lain.

4. Kewajiban penjual kepada pembeli atas pengembalian diskon pembelian akan tereliminasi pada saat:

a. Dilakukan pembayaran kepada pembeli sebesar jumlah potongan setelah dikurangi dengan biaya pengembalian.

b. Dipindahkan sebagai dana kebajikan jika pembeli sudah tidak dapat dijangkau oleh penjual.

5. Potongan angsuran murabahah diakui sebagai berikut:

a. Jika disebabkan oleh pembeli yang membayar secara tepat waktu, maka diakui sebagai pengurang keuntungan murabahah.

b. jika disebabkan oleh penurunan kemampuan pembayaran pembeli, maka diakui sebagai beban.

6. Pengakuan keuntungan. Keuntungan murabahah diakui:

a. Pada saat terjadinya akad murabahah jika dilakukan secara tunai atau secara tangguh sepanjang masa angsuran murabahah tidak melebihi satu periode laporan keuangan.

b. Selama periode akad secara proporsional jika akad melampaui satu periode keuangan.

7. Potongan angsuran murabahah diakui sebagai berikut:

a. Jika disebabkan oleh pembeli yang membayar secara tepat waktu diakui sebagai pengurangan keuntungan murabahah.

b. Jika disebabkan oleh penurunan kemampuan pembayaran pembeli diakui sebagai beban.

8. Pengakuan denda. Denda dikenakan jika pembeli lalai dalam melakukan kewajibannya sesuai dengan akad dan denda yang diterima diakui sebagai dana kebajikan (Pratiwi \& Septiarini, 2014). 
9. Penyajian persentase piutang murabahah. Piutang murabahah disajikan sebesar nilai neto yang dapat direalisasikan yaitu saldo piutang murabahah dikurangi penyisihan kerugian piutang.

10. Penyajian marjin murabahah. Marjin murabahah tangguhan disajikan sebagai pengurang (contra account) piutang murabahah.

11. Kesebelas, Penyajian pembukuan laporan keuangan.Beban murabahah tangguhan disajikan sebagai pengurang (contra account) utang murabahah.

12. Keduabelas, Pengungkapan.

a. Penjual mengungkapkan hal-hal yang terkait dengan transaksi murabahah, tetapitidak terbatas pada:

1) harga perolehan aset murabahah.

2) janji pemesanan dalam murabahah berdasarkan pesanan sebagai kewajiban atau bukan.

3) Pengungkapan yang diperlukan sesuai PSAK 101: Penyajian Laporan Keuangan Syariah.

b. Pembeli mengungkapkan hal-hal yang terkait dengan transaksi murabahah, tetapi tidak terbatas pada:

1) nilai tunai aset yang diperoleh dari transaksi murabahah.

2) jangka waktu murabahah tangguh.

\section{Faktor Penyebab dan Penanganan Pembiayaan Murabahah Bermasalah}

1. Faktor Penyebab Pembiayaan Murabahah Bermasalah

Ada beberapa faktor penyebab pembiayaan bermasalah Sebab-sebab pembiayaan bermasalah dapat berasal dari pihak internal, dan pihak eksternal diantaranya sebagai berikut:

a. Faktor intern (berasal dari pihak BMT)

1) Kurang baiknya pemahaman atas bisnis nasabah;

2) Kurang dilakukan evaluasi keuangan nasabah;

3) Kesalahan setting fasilitas pembiayaan (berpeluang melakukan sidestreaming);

4) Perhitungan modal kerja tidak didasarkan kepada bisnis usaha nasabah;

5) Proyeksi penjualan terlalu optimis;

6) Proyeksi penjualan tidak memperhitungkan kebiasaan bisnis dan kurang memperhitungkan aspek competitor;

7) Aspek jaminan tidak diperhitungkan aspek marketable lemahnya supervisi dan monitoring;

8) Terjadinya erosi mental: kondisi ini dipengaruhi timbali balik antara nasabah dengan pejabat bank sehingga mengakibatkan proses pemberian pembiayaan tidak didasarkan pada praktek perbankan yang sehat.

b. Faktor ekstern (dari pihak nasabah)

1) Karakter nasabah tidak amanah (tidak jujur dalam memberikan informasi dan laporan tentang kegiatannya);

2) Melakukan sidestreaming penggunaan dana;

3) Kemampuan pengelolaan nasabah tidak memadai sehingga kalah dalam persaingan usaha;

4) Usaha yang dijalankan relatif baru;

5) Bidang usaha nasabah telah jenuh;

6) Tidak mampu menanggulangi masalah/ kurang menguasai bisnis; 


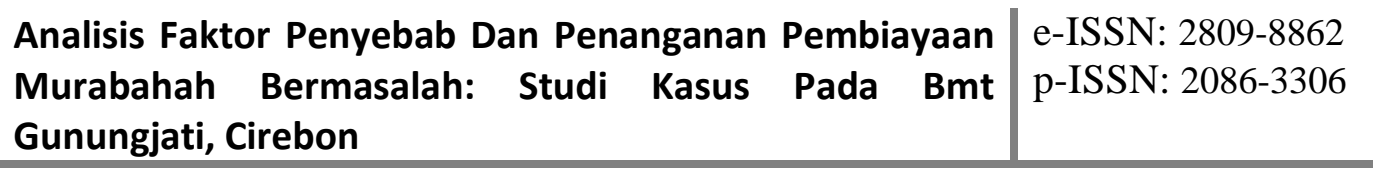

7) Meninggalnya key person;

8) Terjadi bencana alam;

9) Adanya kebijakan pemerintah: peraturan suatu produk atau sektor ekonomi atau industri dapat berdampak positif maupun negatif bagi perusahaan yang berkaitan dengan industri tersebut.

2. Penanganan Pembiayaan Murabahah Bermasalah

Bank syariah dalam memberikan pembiayaan berharap bahwa pembiayaan tersebut berjalan dengan lancar, akan tetapi bisa terjadi dalam jangka waktu pembiayaan nasabah mengalami kesulitan dalam pembayaran yang berakibat kerugian bagi bank syariah (Laina, 2016). Dalam hukum perdata kewajiban memenuhi prestasi harus dipenuhi oleh debitur sehingga jika debitur tidak memenuhi sesuatu yang diwajibkan seperti yang telah ditetapkan dalam perjanjian maka dikatakan debitur telah melakukan wanprestasi (UNIBA \& Nourma Dewi, 2017). Berikut ini akan dijelaskan upaya atau strategi dalam mengatasi pembiayaan murabahah bermasalah:

a. Melakukan pendekatan kepada nasabah pembiayaan. Hal ini dilakukan untuk mengetahui permasalahan yang sedang terjadi pada nasabah pembiayaan. Serta memberikan alternatif solusi dalam mengatasi permasalahan nasabah dengan mendatangi dan mendiskusikannya.

b. Collection, yaitu penagihan secara intensif. Dalam hal ini dilakukan dengan dua cara sebagai berikut: Pertama, penagihan secara persuasive yaitu dengan mengirimkan surat peringatan atau teguran kepada nasabah yang bermasalah. Kedua, penagihan secara langsung yakni dengan mendatangi langsung nasabah pembiayaan murabahah yang mengalami penunggakan (Setiawan \& Amin, 2019).

c. Rescheduling (penjadwalan ulang), yaitu nasabah diberikan perpanjangan waktu jatuh tempo dalam pelunasan pembiayaan yang diberikan oleh bank/BMT.

d. Restructuring, yaitu dengan cara: Menambah jumlah kredit dan/atau menambah equity yaitu dengan menyetor uang tunai dan/atau ambahan dari pemilik (Mulyadi, 2016).

e. Potongan pelunasan, artinya bank/BMT memberikan keringanan kepada nasabah yang bermasalah berupa potongan pelunasan dalam tempo yang telah ditentukan.

f. Penyitaan jaminan, yaitu penjualan barang-barang yang dijadikan jaminan dalam rangka pelunasan pembiayaan (Hasiholan, 2020). Hal ini dilakukan apabila nasabah sudah benar-benar tidak mampu lagi untuk membayar hutangnya.

g. Hapus buku yaitu langkah terakhir yang dilakukan untuk membebaskan nasabah dari beban hutangnya, dikarenakan nasabah sudah tidak mampu lagi untuk mengembalikan pinjamannya dan barang yang dijadikan jaminan tidak bisa menutupi hutangnya. Sedangkan usaha yang dijalaninya sudah tidak bisa diharapkan lagi.

\section{KESIMPULAN}

Sebagaimana dibahas di atas, masih terdapat ketidaksesuaian antara konsep dengan apa yang terjadi di lapangan mengenai pelaksanaan murabahah. Di antara indikasi ketidaksesuaian itu adalah mengenai konsep murabahah bil wakalah (agen kepada nasabah) yang jika tetap dipertahankan lebih mendekati pada jual beli yang diharamkan, 
yaitu jual beli maedum atau jual beli barang yang tidak ada pada seseorang (penjual). Walaupun demikian, masih terdapat dispensasi mengenai pembiayaan murabahah bil wakalah, yaitu jika pihak BMT berada dalam kemadharatan apabila tidak menggunakan pelaksanaan murabahah dengan agen. Faktor yang menyebabkan pembiayaan murabahah bermasalah di BMT Gunungjati dikarenakan pihak BMT (faktor insternal) dan nasabah itu sendiri (faktor eksternal) seperti: Penurunan pendapatan usaha yang diperoleh nasabah, nasabah mengalami kepailitan dan nasabah kesulitan dalam melakukan pembayaran. Sehingga dilakukan penanganan dengan cara dilakukan penjadwalan kembali (rescheduling), penyusunan kembali (restructuring), offset pinjaman (penjualan jaminan) dan penghapusan pembiayaan. Metode pelunasan pembiayaan akad murabahah telah sesuai dengan fatwa DSN dan PSAK 102 mengenai denda atas kelalaian nasabah. Dan potongan atau diskon yang diberikan BMT juga telah sesuai dengan metode yang diatur oleh PSAK 102.

\section{BIBLIOGRAFI}

Al-Hasan, F. A. (2013). Analisis Pelaksanaan Akad Murabahah Di Lembaga Mikro Keuangan Syariah (BMT). Jurnal Mahasiswa Jurusan Hukum Ekonomi Syariah Fakultas Syariah Dan Hukum Uin Sgd Bandung, March 2014.

Febrian, R., \& Mardian, S. (2017). Penerapan PSAK NO. 102 Atas Transaksi Murabahah: Studi Pada Baitul Maal Wa Tamwil Di Depok, Jawa Barat. Ikonomika, 2(1). https://doi.org/10.24042/febi.v2i1.943

Habibah, M., \& Nikmah, A. (2016). Analisis Penerapan Akuntansi Syariah Berdasarkan Psak 102 Pada Pembiayaan Murabahah Di BMT Se-Kabupaten Pati. Jurnal Ekonomi Syariah, 4(1).

Hasiholan, C. P. (2020). Tinjauan Yuridis Atas Penyitaan Barang Oleh Kreditur Terhadap Debitur Yang Wanprestasi Pada Koperasi Kredit Harapan Kita Medan.

Ibrahim, A., \& Rahmati, A. (2017). Analisis solutif penyelesaian pembiayaan bermasalah di bank syariah: Kajian pada produk murabahah di Bank Muamalat Indonesia Banda Aceh. Iqtishadia: Jurnal Kajian Ekonomi Dan Bisnis Islam STAIN Kudus, 10(1), 71-96.

Ibrahim, R., \& Handayani, T. (2009). Penerapan Pernyataan Standar Akuntansi Keuangan Nomor 45 Pada Baitul Mal Provinsi Nanggroe Aceh Darussalam. Jurnal Telaah Dan Riset Akuntansi, 2(2), 183-197.

Laina, Z. (2016). Analisis penyelesaian pembiayaan murabahah bermasalah di BMT Insan Sejahtera Cabang Cepiring. UIN Walisongo.

Mulyadi, D. (2016). Analisis Manajemen Kredit Dalam Upaya Meminimalkan Kredit Bermasalah (Studi Pada PT. BPR Pantura Abadi Karawang). Jurnal Manajemen \& Bisnis Kreatif, 1(2).

Mustofa, A. (2014). Reorientasi Ekonomi Syari'ah. Yogyakarta: UII Press Yogyakarta (Anggota IKAPI).

Pratiwi, I. E., \& Septiarini, D. F. (2014). Analisis Penerapan Psak 102 Murabahah (Studi Kasus Pada KSU BMT Rahmat Syariah Kediri). AKRUAL: Jurnal Akuntansi, 6(1), $17-32$.

Purwanto, M. R. (2019). Keadilan dan Negara: Pemikiran Sayyid Qutb tentang Pemerintahan yang Berkeadilan. Universitas Islam Indonesia.

Setiawan, A., \& Amin, M. (2019). Penanganan Pembiayaan Muarabahah yang Bermasalah di Kopersi Jasa Keuangan Syariah Mandiri Sejahtera Cabang Campurejo Panceng Gresik. Al-Muzdahir: Jurnal Ekonomi Syariah, 1(1), 41-50.

UNIBA, F. H., \& Nourma Dewi, S. H. (2017). Regulasi Keberadaan Baitul Maal Wat 
Tamwil (bmt) dalam Sistem Perekonomian di Indonesia. Serambi Hukum, 11(01), 96-110.

Wardiwiyono, S. (2012). Internal control system for Islamic micro financing: An exploratory study of Baitul Maal wat Tamwil in the City of Yogyakarta Indonesia. International Journal of Islamic and Middle Eastern Finance and Management.

Yuliansyah, A. A. (2013). "Analisis Perlakuan atas Pembiayaan Murabahah Bermasalah" (studi kasus pada BMT PSU (Perdana Surya Utama) Malang). Jurnal Ilmiah Mahasiswa FEB, 1(2).

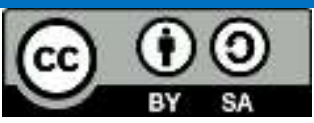

This work is licensed under a Creative Commons Attribution-ShareAlike 4.0 International License 